\title{
Annual cycle of picophytoplankton photosynthesis and growth rates in a temperate coastal ecosystem: a major contribution to carbon fluxes
}

\author{
Xosé Anxelu G. Morán* \\ Centro Oceanográfico de Xixón, Instituto Español de Oceanografía, Camín de L'Arbeyal, s/n, 33212 Xixón, Spain
}

\begin{abstract}
Autotrophic picoplankton (cells $<2 \mu \mathrm{m}$ ) have been comparatively little studied in coastal waters. I present here the seasonal variation of picophytoplankton photosynthetic parameters, primary production and growth rates determined using the ${ }^{14} \mathrm{C}$ method at a shelf station in the southern Bay of Biscay sampled monthly during 2003. Picophytoplankton chlorophyll a (chl a) $\left(11.5 \pm 1.7 \mathrm{mg} \mathrm{m}^{-2}\right.$, mean $\pm \mathrm{SE}$ ) amounted to a mean of $42 \%$ (6 to $63 \%$ ) of euphotic-layer integrated total values. Although prokaryotic cyanobacteria (Synechococcus and Prochlorococcus) generally outnumbered eukaryotic cells, picoeukaryotes were the greatest contributors to total picophytoplankton biomass (54 to $914 \mathrm{mg}$ $\mathrm{C} \mathrm{m}^{-2}$ ) for most of the year. Mean C:chl a ratios ranged from 7 to 89 . The initial slope $\alpha^{\mathrm{B}}$ (0.01 to $0.11 \mathrm{mg}$ $\mathrm{C} \mathrm{mg} \mathrm{chl} a^{-1}$ [ $\mu \mathrm{mol}$ photons $\left.\mathrm{m}^{-2} \mathrm{~s}^{-1}\right]^{-1}$ ) was always higher at depth than at the surface, while the maximum chl a-normalized photosynthetic rate $P_{\mathrm{m}}^{\mathrm{B}}\left(0.6\right.$ to $\left.17.4 \mathrm{mg} \mathrm{C} \mathrm{mg} \mathrm{chl} \mathrm{a}^{-1} \mathrm{~h}^{-1}\right)$ was only significantly higher at the surface during summer, with vertical differences positively correlated to stratification. In contrast, maximum growth rates $\left(\mu_{\max }, 0.1\right.$ to $\left.3.1 \mathrm{~d}^{-1}\right)$ were remarkably similar in surface and deep samples, with maxima in spring and minima in summer and autumn. $\mu_{\max }$ values were significantly correlated with the relative abundance of picoeukaryotes, indicating their prevalence over prokaryotes in coastal ecosystems. Integrated picophytoplankton primary production ranged from 35 to $345 \mathrm{mg} \mathrm{C} \mathrm{m} \mathrm{d}^{-2} \mathrm{~d}^{-1}$ and accounted for a mean annual value of $51 \%$ (4 to $76 \%$ ) of total rates, thus confirming the essential role of small cells in the carbon flux of this temperate coastal ecosystem.
\end{abstract}

KEY WORDS: Picophytoplankton · Photosynthetic parameters · Primary production · Growth rates · Seasonal variability $\cdot$ Coastal waters

Resale or republication not permitted without written consent of the publisher

\section{INTRODUCTION}

Autotrophic cells in the picoplankton size fraction (0.2 to $2 \mu \mathrm{m})$ have been recognized as an important component of microbial plankton communities for more than 2 decades (Stockner 1988). Marine picophytoplankton is composed of both prokaryotic and eukaryotic cells, generally represented by Prochlorococcus and Synechococcus cyanobacteria and by small flagellates belonging to the classes Prasinophyceae and Chlorophyceae, among others (Medlin et al. 2006, Rodríguez et al. 2006). The dominant contribution of picophytoplankton to total phytoplankton standing stocks and carbon fluxes in oligotrophic warm environ- ments is well established (Agawin et al. 2000). Overall, picophytoplanktonic production amounts to $>50 \%$ of total primary production in these areas (Agawin et al. 2000), with a comparatively higher contribution to standing stocks than to photosynthetic rates (Fernández et al. 2003).

Although sometimes considered a minor component of coastal phytoplankton assemblages (Iriarte \& Purdie 1994, Magazzù \& Decembrini 1995) because of higher mixing rates in shelf waters, some older (Joint \& Pomroy 1983, Jochem 1989, Kuosa 1991, Mousseau et al. 1996) and more recent studies (Joint et al. 2001, Murrell \& Lores 2004, Worden et al. 2004, Cermeño et al. 2006) have also highlighted the importance of small 
cells in shelf-sea ecosystems. It has been argued that picophytoplankton may also contribute significantly to photosynthetic carbon fixation in ecosystems with high nutrient loadings (Carrick \& Schelske 1997). However, testing this hypothesis has been impeded by the paucity of data at the adequate spatio-temporal resolution. Joint et al. (1986), who reported maximum primary production rates of cells $<1$ and $5 \mu \mathrm{m}$ in summer in the Celtic Sea, and more recently Cermeño et al. (2006), who determined annual maxima of picophytoplankton contribution to total primary production (30\%) during winter mixing in the Ría de Vigo coastal embayment, are among the few studies describing temporal patterns of primary production by the smallest algal size class in coastal waters.

Ecological research on picophytoplankton populations has been important in elucidating the regulation of abundance, biomass and single-cell properties (Raven 1998). Yet the specific photophysiology of natural picophytoplankton communities has seldom been addressed over a complete annual cycle, in either marine (Joint \& Pomroy 1986) or freshwater ecosystems (Malinsky-Rushansky et al. 1997). In addition to providing the parameters needed for estimating primary production rates from chlorophyll a ( $\mathrm{chl}$ a) standing stocks and the light field distribution, the study of the photosynthesis-irradiance $(P-E)$ relationships can highlight ecophysiological responses to environmental factors, such as nutrient status or water-column stability (Lewis et al. 1984). Seasonal studies of bulk photosynthetic parameters in different regions have identified clear temporal patterns for the maximum chl a-normalized photosynthetic rate $P_{\mathrm{m}}^{\mathrm{B}}$ (Tillmann et al. 2000, Finenko et al. 2002), but have seldom been used for the initial slope $\alpha^{\mathrm{B}}$ (Finenko et al. 2002, Morán \& Estrada 2005). The latter authors found that irradiance explained most of the seasonal variability in both photosynthetic parameters in western Mediterranean surface waters, with nutrients or specific composition playing a minor role. Picophytoplankton carbon biomass can be easily calculated from flow cytometry analysis and empirical calibrations of size versus light scattering signals. Growth rates can thus be estimated without the uncertainties associated with the use of $\mathrm{C}: \mathrm{chl}$ a ratios, which are frequently taken from the literature rather than measured, especially for larger phytoplankton. In this regard, MacIntyre et al. (2002) have argued that carbon-specific rather than chl $a$-specific photosynthetic rates are the relevant mass units for interpreting $P-E$ curves.

Previous work indicates that the picoplanktonic size fraction is a significant component of phytoplankton assemblages in the southern Bay of Biscay continental shelf (Calvo-Díaz et al. 2004, Calvo-Díaz \& Morán 2006), with values exceeding $0.5 \mathrm{~g} \mathrm{C} \mathrm{m}^{-2}$ in summer. In these shelf waters prokaryotes dominate picoplanktonic abundance for most of the year but only sporadically in terms of biomass (Calvo-Díaz \& Morán 2006). Although picophytoplankton abundance and biomass display strong seasonal signals in these waters, their contribution to photosynthetic carbon fixation remains unexplored. Indeed, to the best of my knowledge, this is the first study to address the temporal variability of picophytoplankton photophysiology and carbonfixation dynamics over an entire seasonal cycle in a temperate coastal ecosystem. Researchers may have overlooked the role of picophytoplankton in the carbon budget of these waters because of the occurrence of massive spring blooms of larger cells. However, the sporadic and short-lived nature of microphytoplankton blooms leaves, in principle, enough room for an appraisal of its importance on a yearly basis. The specific aims of this study are to (1) describe the temporal and vertical variability of autotrophic picoplankton photosynthetic parameters, (2) gain insight into the factors affecting picophytoplankton growth rates, and (3) estimate the annual contribution of picophytoplankton to total algal biomass and primary production in southern Bay of Biscay shelf waters. I conclude that for most of the year, small-celled phytoplankton is fundamental for photosynthetic carbon fixation in this shelf-sea ecosystem, with a mean overall contribution as high as that of the nano- and microphytoplankton size fractions combined.

\section{MATERIALS AND METHODS}

Samples were taken monthly during 2003 at Stn 2 $\left(43.7^{\circ} \mathrm{N}, 5.6^{\circ} \mathrm{W}, 110 \mathrm{~m}\right.$ depth) located in the standard RADIALES transect off Xixón in the central Cantabrian Sea (southern Bay of Biscay) on board the RV 'José de Rioja.'

Environmental properties. Vertical profiles of temperature, salinity and fluorescence were obtained with a SeaBird 25 CTD probe equipped with Sea-Point fluorometer. Water-column irradiance in the PAR range (400 to $700 \mathrm{~nm}$ ) was measured during the CTD casts with a Biospherical QSP-2200 spherical quantum sensor. Vertical profiles of ln-PAR permitted the calculation of the vertical light extinction coefficients $\left(k_{d}\right)$. The bottom of the euphotic zone was established at the $1 \%$ isolume and ranged from 27 to $74 \mathrm{~m}$. Surface irradiance ( $\mu \mathrm{mol}$ photons $\mathrm{m}^{-2} \mathrm{~s}^{-1}$ ) during the day of sampling was measured at 10 min intervals in the laboratory by an air/underwater quantum sensor (LI-192SA, LI-COR) connected to a LI-1400 data logger. The combination of both measurements allowed the estimation of hourly changes in irradiance at each sampling depth. The mixed-layer depth was calculated as the depth at which 
a density $\left(\sigma_{t}\right)$ change $\geq 0.05 \mathrm{~kg} \mathrm{~m}^{-3}$ over a $5 \mathrm{~m}$ interval was first attained. A stratification index (SI) was calculated as the per-meter difference in $\sigma_{t}$ between the surface and $100 \mathrm{~m}$ depth.

Duplicate $100 \mathrm{ml}$ samples for estimating total and greater than $2 \mu \mathrm{m} \operatorname{chl} a$ concentrations in the $P$-E experiments were respectively filtered through Millipore membrane esters $(0.22 \mu \mathrm{m}$ pore size) and polycarbonate filters ( $2 \mu \mathrm{m}$ pore size) of $25 \mathrm{~mm}$ diameter, which were immediately frozen until extraction. In parallel, as part of the plankton time-series sampling at the same station, $100 \mathrm{ml}$ samples taken at 8 discrete depths $(0,10,20,30,40,50,75$ and $100 \mathrm{~m})$ were sequentially filtered through 20, 2 and $0.2 \mu \mathrm{m}$ Millipore polycarbonate filters (47 $\mathrm{mm}$ diameter). Filters were analyzed within $1 \mathrm{wk}$, placed in $90 \%$ acetone at $4^{\circ} \mathrm{C}$ for $24 \mathrm{~h}$ and the fluorescence of the extract was measured without acidification (Welschmeyer 1994) using a Perkin Elmer LB50s spectrofluorometer (excitation at $440 \mathrm{~nm}$, emission at $685 \mathrm{~nm})$, periodically calibrated with pure chl a. Chl $a$ in the picoplanktonic size fraction (picochl a) was estimated as the difference between the amounts retained on the 0.22 and $2 \mu \mathrm{m}$ filters.

Samples for analyzing dissolved inorganic nitrogen $\left(\mathrm{DIN}=\mathrm{NO}_{2}{ }^{-}+\mathrm{NO}_{3}{ }^{-}+\mathrm{NH}_{4}{ }^{+}\right)$, phosphate and silicate were immediately frozen and their concentrations determined in the laboratory with a Technicon autoanalyzer.

Picophytoplankton abundance and biomass. The abundance of 4 different groups of picophytoplankton (Synechococcus, Prochlorococcus and small and large picoeukaryotes) was determined at the 8 discrete depths mentioned in the previous section and additionally at the depths of the $P$-E experiments (Table 1). Within $3 \mathrm{~h}$ of water collection, $1.8 \mathrm{ml}$ samples were taken in cryovials, fixed with $1 \%$ paraformaldehyde plus $0.05 \%$ glutaraldehyde (final concentration) and stored frozen at $-80^{\circ} \mathrm{C}$ until analysis with a FACSCalibur (Becton-Dickinson) flow cytometer, generally within $2 \mathrm{wk}$. Thawed samples $(0.6 \mathrm{ml})$ were then analyzed at a high flow rate (ca. $50 \mu \mathrm{l} \mathrm{min}^{-1}$ ) for $5 \mathrm{~min}$. I used flow rate for estimating absolute abundances after daily detection of possible changes by gravimetric calibration with Milli-Q water run for $10 \mathrm{~min}$. Red (FL3) and orange (FL2) fluorescence, together with right-angle light scatter (RALS) signals allowed me to unequivocally distinguish between these 4 groups. Cell sizes (diameter in $\mu \mathrm{m}$ ) of the different groups were estimated from an empirical calibration with picophytoplankton RALS values made relative to the corresponding signal of fluorescent latex beads (1 $\mu \mathrm{m}$ diameter, Molecular Probes, ref. F-13081): cell size $=1.62+0.87 \log$ RALS, $\mathrm{r}^{2}=0.84, \mathrm{p}<0.001, \mathrm{n}=16$. Picophytoplankton biomass was finally calculated

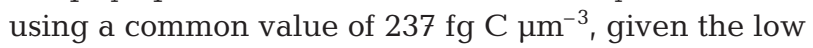
variability of carbon to biovolume conversion factors in coastal picophytoplankton (Worden et al. 2004). More details can be found in Calvo-Díaz \& Morán (2006). Integrated values for the euphotic layer (pico-PB) were calculated by trapezoidal integration.

Photosynthesis-irradiance relationships. Every month samples for the $P-E$ experiments were collected at the surface and the depth of the subsurface fluorescence maximum, which ranged from 20 to $60 \mathrm{~m}$ (Table 1). At each depth, 11 light bottles plus 1 dark bottle were filled with $70 \mathrm{ml}$ of water, inoculated with $\sim 3.7 \times 10^{5} \mathrm{~Bq}$ ${ }^{14} \mathrm{C}$-bicarbonate, and incubated for ca. $2 \mathrm{~h}$ in a linear incubator flushed with freshwater at in situ tempera- 
ture $\left( \pm 1.5^{\circ} \mathrm{C}\right)$. Quartz halogen lamps were used as the light source. Irradiance levels at each position (range 5 to $2000 \mu \mathrm{mol}$ photons $\mathrm{m}^{-2} \mathrm{~s}^{-1}$ ) were measured after each experiment with an underwater quantum sensor (LI-COR LI-192SA).

In order to eliminate possible breakage of cells and enrichment of the samples during the incubation (Joint \& Pomroy 1983), the whole water sample was incubated; at the end of the experiment, 40 and $30 \mathrm{ml} \mathrm{sub-}$ samples of it were filtered onto 2 and $0.22 \mu \mathrm{m}$ filters, respectively, of the same type as those used for chl a measurements. The amount of radioactivity incorporated by picoplanktonic autotrophs was estimated as the difference between that retained on the 0.22 and $2 \mu \mathrm{m}$ filters. Filtration through $2 \mu \mathrm{m}$ filters resulted in an average retention of $53 \pm 4 \%$ of large eukaryotes due to their greater size (Table 2), while virtually all cyanobacteria of both genera $(92 \pm 5 \%)$ and small eukaryotes $(90 \pm 5 \%$ ) passed through the filters.

Since most of the samples did not show photoinhibition for the experimental irradiance range, the $P-E$ model of Webb et al. (1974) was fitted to chl a-normalized hourly carbon production rates to derive the photosynthetic parameters. The model of Platt et al. (1980) was used when photoinhibition was detected. The photosynthetic parameters considered hereafter are: the maximum or light-saturated chl a-normalized photosynthetic rate $P_{\mathrm{m}}^{\mathrm{B}}\left(\mathrm{mg} \mathrm{C} \mathrm{mg} \mathrm{chl} \mathrm{a}^{-1} \mathrm{~h}^{-1}\right)$, the initial or light-limited slope of the P-E relationship $\alpha^{\mathrm{B}}$ [mg C mg chl $a^{-1} h^{-1}$ ( $\mu$ mol photons $\left.\mathrm{m}^{-2} \mathrm{~s}^{-1}\right)^{-1}$ ], the photoinhibition parameter $\beta^{\mathrm{B}}$ (same units as $\alpha^{\mathrm{B}}$ ) and the light saturation parameter or saturation irradiance $E_{\mathrm{k}}$ ( $\mu \mathrm{mol}$ photons $\mathrm{m}^{-2} \mathrm{~s}^{-1}$ ).

Primary production and growth rates. Photosynthetic parameters were used in conjunction with the vertical distribution of picophytoplankton chl $a$ and

Table 2. Seasonal variation of cell-size (diameter, $\mu \mathrm{m}$ ) of the different picophytoplanktonic groups averaged for the euphotic layer. Abbreviations as in Table 1

\begin{tabular}{|lcccc|}
\hline Month & Syne & Proc & Small & Large \\
\hline Jan & 1.00 & 0.74 & 1.35 & 2.07 \\
Feb & 0.96 & & 1.22 & 2.00 \\
Mar & 1.01 & & 1.30 & 1.88 \\
Apr & 1.05 & & 1.28 & 2.16 \\
May & 0.95 & & 1.18 & 1.97 \\
Jun & 0.83 & & 1.25 & 1.96 \\
Jul & 0.86 & & 1.38 & 1.82 \\
Aug & 0.89 & 0.52 & 1.40 & 1.88 \\
Sep & 0.92 & 0.59 & 1.35 & 1.90 \\
Oct & 0.98 & 0.72 & 1.29 & 1.72 \\
Nov & 0.97 & 0.63 & 1.34 & 1.93 \\
Dec & 1.01 & 0.74 & 1.39 & 1.96 \\
${ }^{a}$ Values estimated from only 2 sampling depths & \\
\hline
\end{tabular}

PAR irradiance at the time of sampling for estimating volumetric primary production rates at the 8 depths at which picophytoplankton abundance and biomass were determined. Since only 2 depths were sampled for $P$-E experiments (Table 1), linear interpolation between surface and deep values was used to ascribe photosynthetic parameters to discrete depths. The deeper values were used throughout the rest of the euphotic layer. No correction of dark respiration was attempted. The values given herein should therefore be considered as estimates of the net particulate primary production by picophytoplankton over the daylight period (Marra 2002). Trapezoidal integration was used to estimate integrated primary production by picophytoplankton (pico-PP) over the euphotic layer. Although some researchers have cautioned against the use of photosynthetic parameters derived from artificial light sources for estimating in situ primary production, the limited number of studies comparing in situ-measured and $P$-E-derived carbon fixation rates have failed to show significant underestimations with the latter method, especially in the absence of deep maxima in phytoplankton biomass (see references and discussion in Morán \& Estrada 2005).

Picophytoplankton specific growth rates $\left(\mu, d^{-1}\right)$ averaged for the euphotic layer were calculated from integrated primary production and biomass values assuming exponential growth: $\mu=\ln [1+$ (pico-PP/ pico-PB)]. Maximum growth rates $\left(\mu_{\max }\right)$ were also estimated in surface and deep samples from $P^{\mathrm{B}}$ values and discrete C:chl a ratios as: $\mu_{\max }=\ln \left[1+\left(P_{\mathrm{m}}^{\mathrm{B}} \times\right.\right.$ daylight h / C:chl a)].

\section{RESULTS}

\section{Environmental properties}

Although temperature at the study site was uniformly distributed with depth in autumn and winter (Fig. 1A), the presence of low salinity lenses at the surface during these months (Fig. 1B) resulted in shallower-than-expected mixed layers (ca. 30 m, cf. with November and December; dashed line in Fig. 1A). The mixed-layer depth was shallowest $(<20 \mathrm{~m})$ coincident with the summer stratification period. Euphotic-layer depth ranged from 27 to $74 \mathrm{~m}$ (Fig. 1C) and was minimum $(\sim 40 \mathrm{~m})$ in winter and spring and maximum in summer $(\sim 70 \mathrm{~m})$. Total chl a values were greatest $\left(>1 \mathrm{~g} \mathrm{l}^{-1}\right.$ ) in April and a relatively deep (50 to $60 \mathrm{~m}$ ) chl a maximum with values $>0.6 \mu \mathrm{g} \mathrm{l}^{-1}$ was apparent in summer (Fig. 1C). Picoplanktonic chl $a$ in the experiments varied from 0.07 to $1.21 \mu \mathrm{g} \mathrm{l}^{-1}$ and was generally higher in deep samples, except in autumn (Table 1). Nitrate, which was taken as a proxy of nutrient fluxes, 

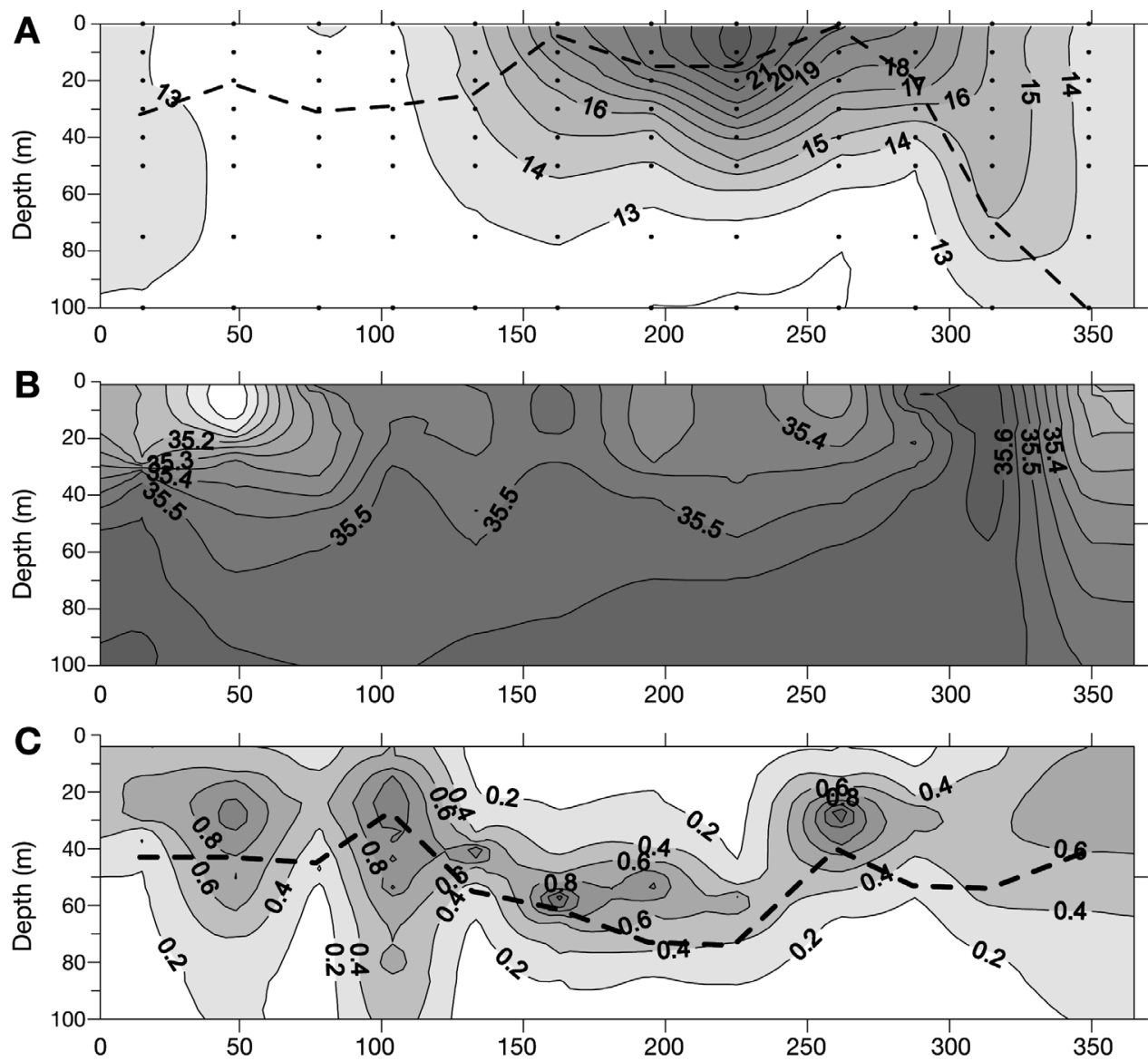

Fig. 1. Vertical distribution of (A) temperature $\left({ }^{\circ} \mathrm{C}\right),(\mathrm{B})$ salinity, (C) total chl a $\left(\mu \mathrm{g} \mathrm{l}^{-1}\right)$, and (D) nitrate concentration $\left(\mu \mathrm{mol} \mathrm{l} \mathrm{l}^{-1}\right.$ ), during 2003 at the study site. Dashed line in (A) represents depth of the upper mixed layer. Dashed line in (C) represents euphotic layer depth $(1 \%$ surface irradiance). Sampling depths and dates are represented as dots in (A)

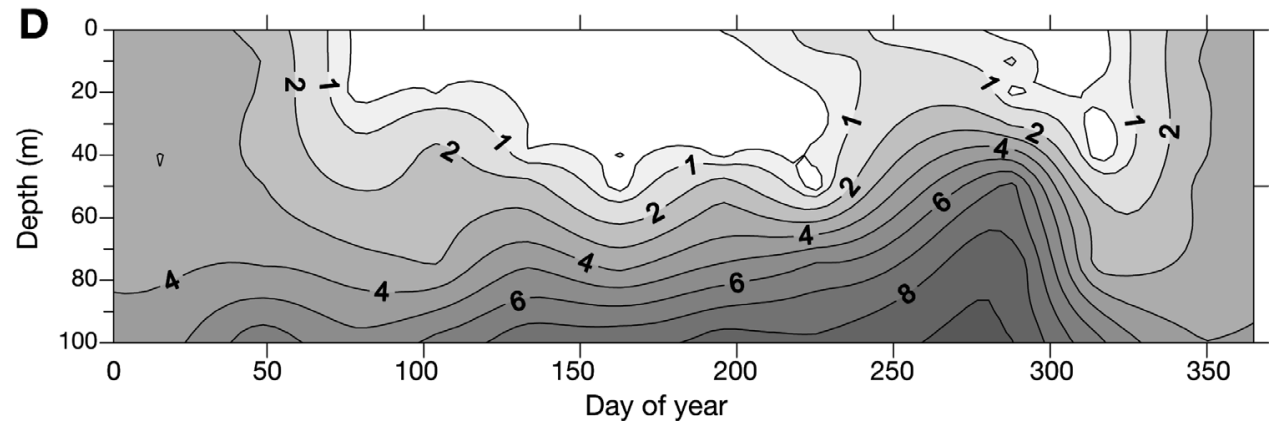

showed a marked seasonal cycle, with limiting concentrations $\left(<1 \mu \mathrm{mol} \mathrm{l}^{-1}\right)$ in the upper layers of the water column from April through July (Fig. 1D).

\section{Picophytoplankton abundance and biomass}

Abundance in the water samples used for the $P-E$ experiments (Table 1) closely reflected that of the euphotic layer. Differences in dominance were observed throughout the year, with picoeukaryotes prevailing in late winter and early spring and cyanobacteria during the remaining period. Synechococcus ranged between 9 and $74 \times 10^{3}$ cells $\mathrm{ml}^{-1}$.
Prochlorococcus was only detected in appreciable numbers in late summer and autumn, with maxima in August and October exceeding $10^{5}$ cells $\mathrm{ml}^{-1}$ and a minimum in January of $<10^{3}$ cells $\mathrm{ml}^{-1}$. Abundance for both small and large picoeukaryote groups peaked in June $\left(2.3 \times 10^{4}\right.$ cells $\mathrm{ml}^{-1}$ for small and $4.2 \times 10^{3}$ cells $\mathrm{ml}^{-1}$ for large), with minima generally found in early spring (3.6 and $0.7 \times 10^{3}$ cells $\mathrm{ml}^{-1}$, respectively), as was the case with Synechococcus. The small group was on average 8-fold more abundant than the large group throughout the year. The relative contribution of prokaryotes to total picophytoplankton abundance was similar in surface and deep samples $(\mathrm{r}=0.74, \mathrm{p}=$ 0.006 ; paired $t$-test, $\mathrm{p}=0.40, \mathrm{n}=12$ ), indicating that 
seasonal differences were more important than stratification in determining the composition of the picophytoplanktonic assemblage. Prokaryotic contribution was $<50 \%$ from February through April, when Synechococcus numbers abruptly drop and Prochlorococcus disappears (Calvo-Díaz \& Morán 2006). Prokaryotic contribution decreased significantly at higher pico-chl a levels $(\mathrm{r}=-0.49, \mathrm{p}=0.016, \mathrm{n}=24)$.

Temporal changes in cell size were relatively minor for Synechococcus and picoeukaryotes (coefficient of variation [CV] 5 to $7 \%$ ) and more pronounced for Prochlorococcus (CV $14 \%$ ). Mean diameters were $0.96 \mu \mathrm{m}$ for Synechococcus, $0.64 \mu \mathrm{m}$ for Prochlorococcus, $1.30 \mu \mathrm{m}$ for small picoeukaryotes and $1.95 \mu \mathrm{m}$ for large picoeukaryotes (Table 2). Given this low variability, total picophytoplankton biomass integrated for the euphotic layer was mainly driven by changes in abundance. Values were generally higher during summer and autumn, frequently exceeding $0.5 \mathrm{~g} \mathrm{C} \mathrm{m}^{-2}$ (Table 3). Due to larger individual carbon content, picoeukaryotes were the greatest contributors to picophytoplankton biomass for most of the year $(73 \pm 7 \%$, mean \pm SE). Biomass of eukaryotes exceeded that of prokaryotes except in August, October and December. Fig. 2C shows the contribution of eukaryotes to total picophytoplankton carbon at the $P-E$ experiments sampling depths. Table 3 also shows integrated picophytoplankton chl a values, which varied between 3.5 and $25.1 \mathrm{mg} \mathrm{m}^{-2}$ with an annual mean of $12.2 \mathrm{mg} \mathrm{m}^{-2}$. Pico-chl a accounted for a minimum of $6 \%$ (April) and a maximum of $63 \%$ (August) of total values, with a mean annual value of $42 \%$. The annual averages of nano- and microphytoplankton size classes were 41 and $17 \%$, respectively.

$\mathrm{C}: \mathrm{chl}$ a ratios in the experimental samples ranged from 8 to 74 (data not shown). Values were signifi-

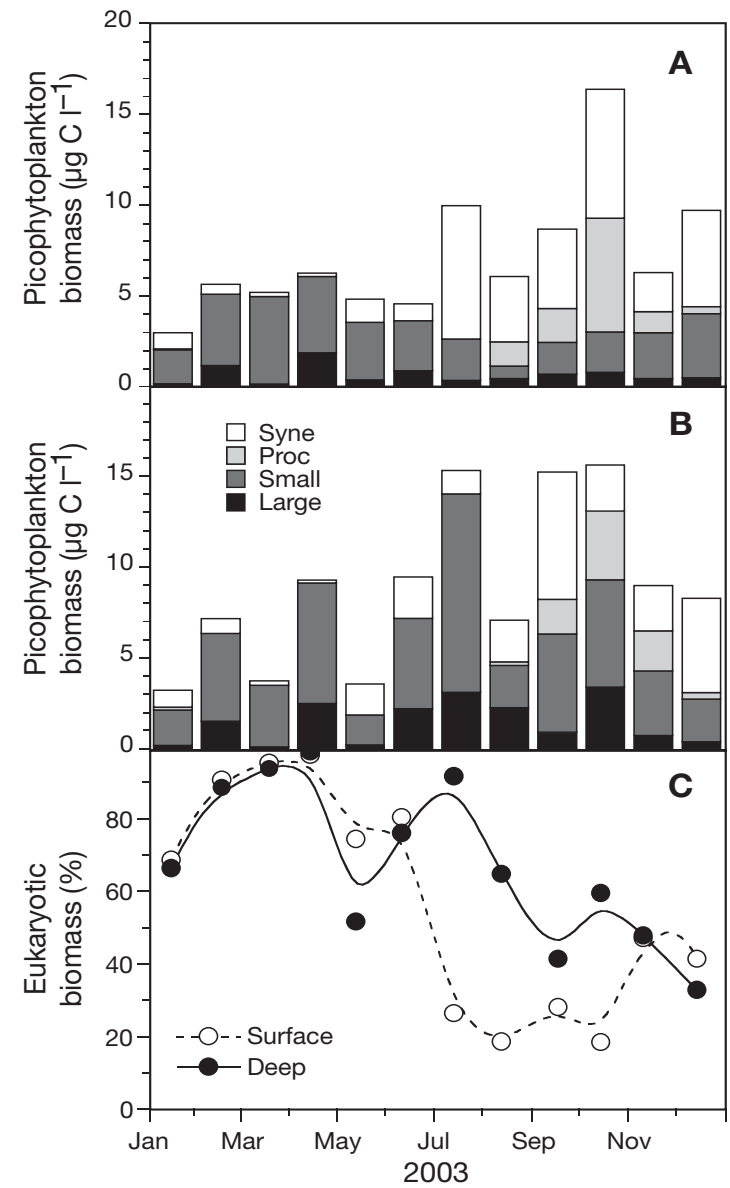

Fig. 2. Biomass of different picophytoplanktonic groups (Syne: Synechococcus; Proc: Prochlorococcus; Small: small eukaryotes; Large: large eukaryotes) at depths of the photosynthesisirradiance $(P-E)$ experiments: (A) surface samples, (B) deep samples, (C) proportion of eukaryotic cells (Small and Large picoeukaryotes) in total picophytoplankton biomass in surface and deep samples

Table 3. Euphotic layer-integrated values of picophytoplankton chl $a$, biomass and percent contribution of the 4 groups, and primary production and growth rates $(\mu)$ in each month. In parentheses in both chl $a$ and primary production columns are the relative contributions (\%) of picophytoplankton to total values. Annual means \pm SE are also shown. Abbreviations as in Table 1

\begin{tabular}{|c|c|c|c|c|c|c|c|c|}
\hline Month & $\begin{array}{c}\mathrm{Chl} \mathrm{a} \\
\left(\mathrm{mg} \mathrm{m}^{-2}\right)\end{array}$ & $\begin{array}{c}\text { Biomass } \\
\left(\mathrm{mg} \mathrm{C} \mathrm{m}^{-2}\right)\end{array}$ & $\begin{array}{l}\text { Syne } \\
(\%)\end{array}$ & $\begin{array}{l}\text { Proc } \\
(\%)\end{array}$ & $\begin{array}{c}\text { Small } \\
(\%)\end{array}$ & $\begin{array}{c}\text { Large } \\
(\%)\end{array}$ & $\begin{array}{l}\text { Primary produc- } \\
\text { tion }\left(\mathrm{mg} \mathrm{C} \mathrm{m}^{-2} \mathrm{~d}^{-1}\right)\end{array}$ & $\underset{\left(d^{-1}\right)}{\mu}$ \\
\hline Jan & $25.1(48)$ & 166 & 24 & 1 & 51 & 25 & $196(72)$ & 0.78 \\
\hline Feb & $16.4(47)$ & 241 & 14 & 0 & 47 & 39 & $122(25)$ & 0.23 \\
\hline Mar & 6.7 (18) & 107 & 11 & 0 & 83 & 7 & $148(47)$ & 0.91 \\
\hline Apr & 3.5 (6) & 54 & 7 & 0 & 47 & 47 & $62(4)$ & 0.61 \\
\hline May & 6.0 (33) & 178 & 35 & 0 & 28 & 37 & $310(66)$ & 1.01 \\
\hline Jun & $10.3(48)$ & 914 & 34 & 0 & 39 & 27 & 156 (63) & 0.16 \\
\hline $\mathrm{Jul}^{\mathrm{a}}$ & 13.8 & 633 & 20 & 0 & 63 & 17 & $205(76)$ & 0.28 \\
\hline Aug & $14.8(63)$ & 546 & 48 & 23 & 15 & 13 & $345(67)$ & 0.49 \\
\hline Sep & $10.4(35)$ & 514 & 41 & 9 & 27 & 24 & 158 (29) & 0.27 \\
\hline Oct & $14.1(62)$ & 347 & 48 & 16 & 21 & 14 & $325(71)$ & 0.66 \\
\hline Nov & $17.4(57)$ & 318 & 28 & 19 & 40 & 13 & $233(67)$ & 0.55 \\
\hline Dec & $8.2(38)$ & 685 & 51 & 3 & 33 & 12 & 35 (23) & 0.05 \\
\hline Mean $\pm \mathrm{SE}$ & $\begin{array}{c}12.2 \pm 1.7 \\
(42 \pm 5)\end{array}$ & $392 \pm 77$ & $28 \pm 17$ & $6 \pm 3$ & $36 \pm 6$ & $22 \pm 4$ & $\begin{array}{c}212 \pm 27 \\
(51 \pm 7)\end{array}$ & $0.57 \pm 0.12$ \\
\hline
\end{tabular}




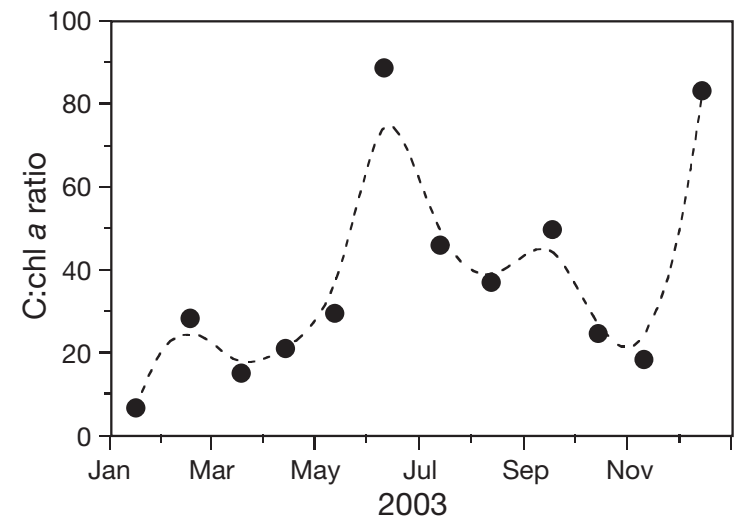

Fig. 3. Monthly variation of picophytoplanktonic C:chl a ratios integrated for the euphotic layer of the sampled station. Dashed line represents smooth fitting to data

cantly higher in surface samples $(43 \pm 20$, mean \pm SD) compared with deep samples $(29 \pm 16$, paired $t$-test, $\mathrm{p}=0.04, \mathrm{n}=12$ ). Corresponding average values for the euphotic layer varied between 7 and 89 (Fig. 3) and, with the exception of the unexpectedly high December value, they were generally higher during summer. Variability in C:chl a ratios was mainly driven by changes in biomass rather than pigment content given the higher variation of the former (17-vs. 10-fold, respectively).

\section{Photosynthetis-irradiance relationships}

Photoinhibition was only observed in the deep samples of July and August, with a common $\beta^{\mathrm{B}}$ value of $0.0003 \mathrm{mg} \mathrm{C} \mathrm{mg} \mathrm{chl} a^{-1} \mathrm{~h}^{-1}\left(\mu \mathrm{mol} \text { photons } \mathrm{m}^{-2} \mathrm{~s}^{-1}\right)^{-1} \cdot \alpha^{\mathrm{B}}$ ranged 1 order of magnitude, from 0.01 to $0.11 \mathrm{mg} \mathrm{C}$ mg chl $a^{-1} \mathrm{~h}^{-1}$ ( $\mu$ mol photons $\left.\mathrm{m}^{-2} \mathrm{~s}^{-1}\right)^{-1}$ (Fig. 4A), and was significantly higher ( $>2$-fold on average) in deep samples than at the surface (paired $t$-test, $\mathrm{p}<0.001, \mathrm{n}=$ 11), with absolute values significantly correlated with sampling depth $(r=0.59, p=0.003, n=23)$. Highest $\alpha^{B}$ values were found in spring, with values mostly around 0.02 (surface) and 0.03 (deep) mg C mg chl $a^{-1}$ $\mathrm{h}^{-1}$ ( $\mu \mathrm{mol}$ photons $\left.\mathrm{m}^{-2} \mathrm{~s}^{-1}\right)^{-1}$ for the rest of the year (Fig. 4A). In situ irradiance levels were significantly and inversely correlated with $\alpha^{\mathrm{B}}$ values $(\mathrm{r}=-0.47, \mathrm{p}=$ $0.02, \mathrm{n}=23$ ).

$P^{\mathrm{B}}$ or assimilation numbers ranged from 0.6 to $17.4 \mathrm{mg} \mathrm{C} \mathrm{mg}$ chl $a^{-1} \mathrm{~h}^{-1}$ (Fig. 4B). Although differences associated with sampling depth were not significant year round (paired $t$-test, $\mathrm{p}=0.41, \mathrm{n}=11$ ), surface and deep $P_{\mathrm{m}}^{\mathrm{B}}$ values exhibited no significant correlation due to a markedly different seasonality. Maximum $P_{\mathrm{m}}^{\mathrm{B}}$ at the surface was found in summer, while deep $P_{\mathrm{m}}^{\mathrm{B}}$ was highest in spring. This different behaviour was a consequence of the physical separation of the

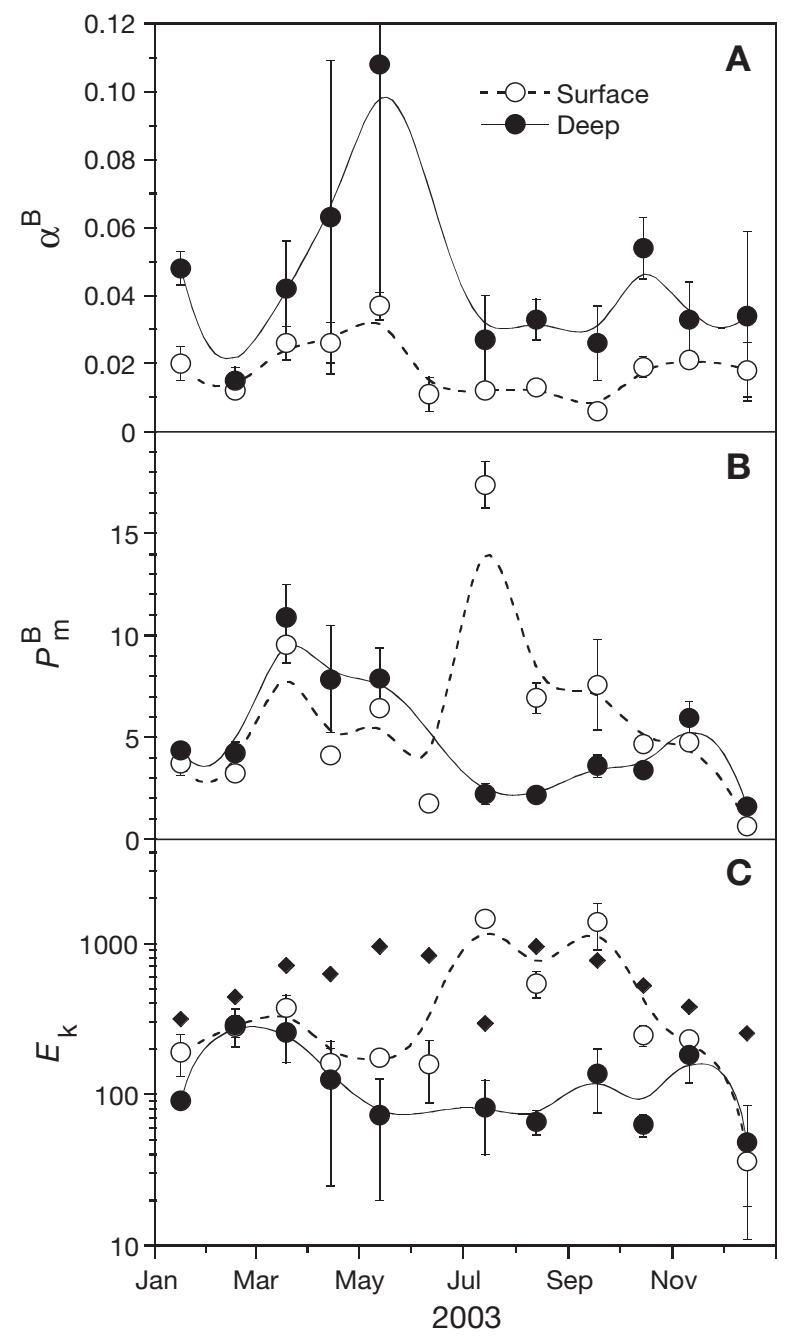

Fig. 4. Monthly variation of picophytoplankton photosynthetic parameters during $( \pm \mathrm{SE}) 2$ 2003. (A) Initial slope of the $P$ - $E$ relationship $\left[\alpha^{\mathrm{B}}, \mathrm{mg} \mathrm{C} \mathrm{mg} \mathrm{chl} a^{-1} \mathrm{~h}^{-1}\left(\mu \mathrm{mol} \text { photons } \mathrm{m}^{-2} \mathrm{~s}^{-1}\right)^{-1}\right.$ ], (B) maximum chl a-normalized photosynthetic rate $\left(P_{\mathrm{m}}^{\mathrm{B}}\right.$, $\left.\mathrm{mg} \mathrm{C} \mathrm{mg} \mathrm{chl} a^{-1} \mathrm{~h}^{-1}\right)$, and (C) saturation irradiance $\left(E_{\mathrm{k}}\right.$, $\mu \mathrm{mol}$ photons $\left.\mathrm{m}^{-2} \mathrm{~s}^{-1}\right)$; : mean incident irradiance during the sampling day. Smooth fittings are shown for visual reference

euphotic zone into 2 layers in summer. Hence, stabilization of the water column induced in situ photoacclimation of picophytoplankton maximum photosynthetic rates, likely mediated by changes in cellular chl a content as observed in flow cytometry FL3 signal (Calvo-Díaz \& Morán 2006). As can be seen in Fig. 5A, the per-meter difference in $P_{\mathrm{m}}^{\mathrm{B}}$ between surface and deep samples was significantly correlated with stratification index $(\mathrm{r}=0.80, \mathrm{p}=0.003, \mathrm{n}=11)$ while that of $\alpha^{\mathrm{B}}$ was not $(p=0.29$, Fig. $5 B) . P_{m}^{B}$ was also inversely correlated with nitrate concentrations $(\mathrm{r}=-0.52, \mathrm{p}=$ 0.009, $\mathrm{n}=23$ ).

$E_{\mathrm{k}}$ values ranged from 36 to $1448 \mu \mathrm{mol}$ photons $\mathrm{m}^{-2}$ $\mathrm{s}^{-1}$ (Fig. 4C) and tended to covary with daily irradiance values at the sampled depths $(r=0.38, p=0.07, n=23)$. 


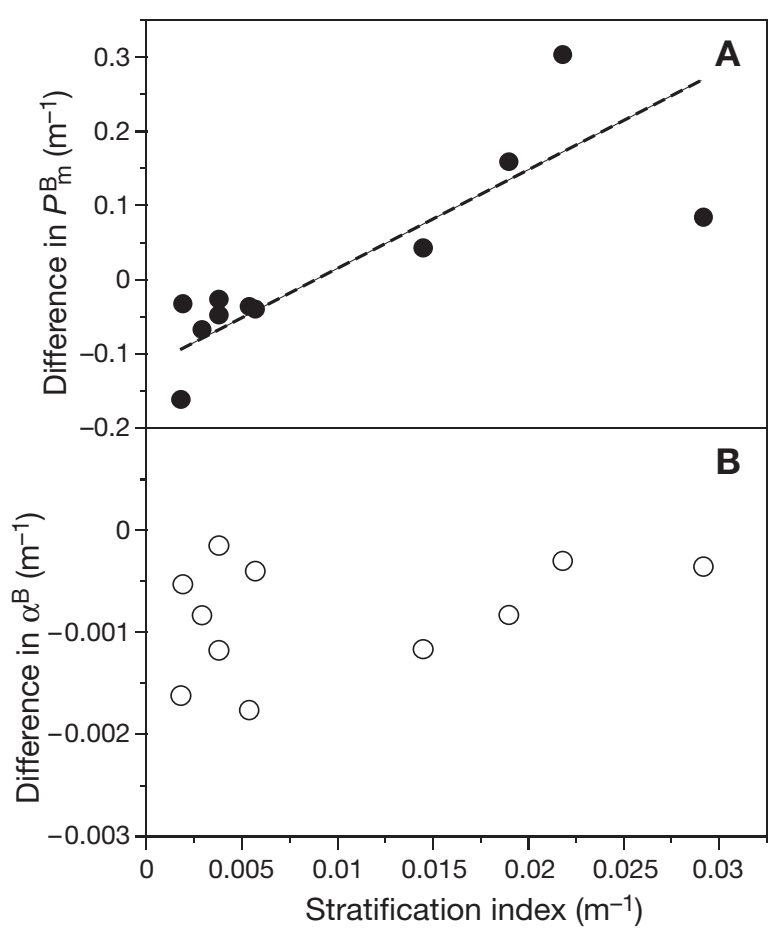

Fig. 5. (A) Relationship between per-meter difference in maximum chl a-normalized photosynthetic rates [(surface $P_{\mathrm{m}}^{\mathrm{B}}-$ deep $P_{\mathrm{m}}^{\mathrm{B}}$ ) / depth] and stratification index. Fitted line represents Model II linear regression: $(r=0.75, \mathrm{p}<0.001, \mathrm{n}=12)$. (B) Relationship between per-meter difference in the lightlimited slope of the $P-E$ relationship [( $\left.\operatorname{surface} \alpha^{\mathrm{B}}-\operatorname{deep} \alpha^{\mathrm{B}}\right) /$ depth] and stratification index

Although differences between the 2 depths were only marginally significant (paired $t$-test, $\mathrm{p}=0.052, \mathrm{n}=11$ ), higher values were consistently found at the surface (on 9 occasions). $P_{\mathrm{m}}^{\mathrm{B}}$ and $\alpha^{\mathrm{B}}$ covariation was not significant for all data pooled; hence, picophytoplankton showed an ' $E_{\mathrm{k}}$-dependent' variability (Behrenfeld et al. 2004) at the sampled station, i.e. cells changed $P_{\mathrm{m}}^{\mathrm{B}}$ and $\alpha^{B}$ in an independent manner, resulting in significant photoacclimation on an annual basis (Fig. 4C).

Differences between picoplanktonic and nano- plus microplanktonic (i.e. $>2 \mu \mathrm{m}$ ) photosynthetic parameters concurrently measured in the same experiments (data not shown) were only significant for $P^{\mathrm{B}}$ (paired $t$-test, $\mathrm{p}=0.018, \mathrm{n}=22$, one outlier excluded), with consistently higher values in the picoplankton size fraction $\left(\right.$ mean \pm SE, $5.44 \pm 0.78 \mathrm{mg} \mathrm{C} \mathrm{mg} \mathrm{chl} a^{-1} \mathrm{~m}^{-3} \mathrm{~h}^{-1}$ ) than in the nano- plus microplanktonic size fraction (3.54 \pm $0.46 \mathrm{mg} \mathrm{C} \mathrm{mg} \mathrm{chl} \mathrm{a}^{-1} \mathrm{~m}^{-3} \mathrm{~h}^{-1}$ ).

\section{Primary production and growth rates}

Volumetric rates of picophytoplankton primary production usually peaked in the upper $20 \mathrm{~m}$, although maximum biomass was sometimes attained deeper in the water column, especially in summer (data not shown). Maximum values usually did not exceed $10 \mathrm{mg} \mathrm{C} \mathrm{m}{ }^{-3} \mathrm{~d}^{-1}$ and minima of 0.5 to $\mathrm{mg} \mathrm{C} \mathrm{m}^{-3} \mathrm{~d}^{-1}$ characterized the base of the euphotic zone. Integrated pico-PP values varied over 1 order of magnitude, from 35 to $345 \mathrm{mg} \mathrm{C} \mathrm{m}^{-2} \mathrm{~d}^{-1}$. With the exception of relatively low values from February through April, no clear seasonal pattern was found; values exceeding $300 \mathrm{mg}$ $\mathrm{C} \mathrm{m}^{-2} \mathrm{~d}^{-1}$ were found in May, August and October (Table 3). The relative contribution of picophytoplankton to total primary production ranged from 4 to $76 \%$, and averaged $51 \pm 7 \%$ (mean $\pm \mathrm{SE}$ ). Higher values $(>60 \%$ ) were consistently found in summer, and on only 5 occasions were values below $50 \%$ (from February through April, and in September and December).

Mean picophytoplankton $\mu$ were highest $\left(\sim 1 \mathrm{~d}^{-1}\right)$ in winter and early spring, coincident with the timing of larger phytoplankton blooms. During the rest of the year values were generally below $0.5 \mathrm{~d}^{-1}$ (Table 3 ). $\mu_{\max }$ at the depths of the $P-E$ experiments are shown in Fig. 6A. Again, highest values $\left(>1.5 \mathrm{~d}^{-1}\right)$ were found in winter and early spring. Unlike with $P^{\mathrm{B}}$, surface and

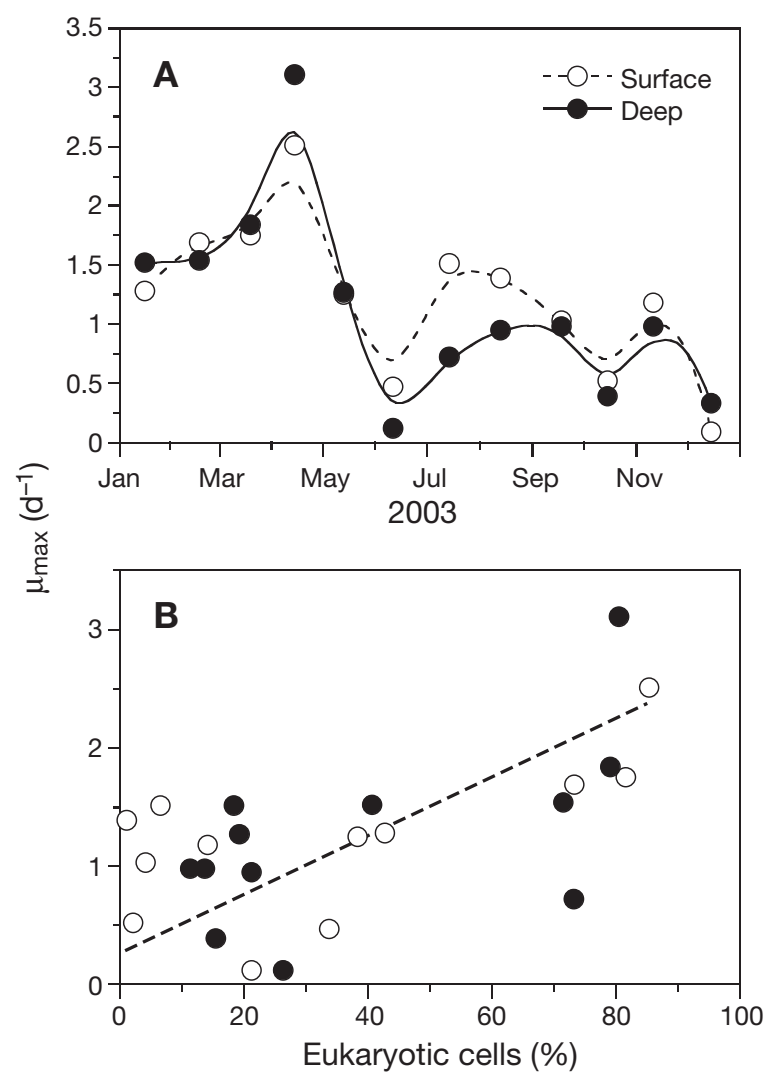

Fig. 6. (A) Monthly variation of picophytoplankton maximum specific growth rates $\left(\mu_{\max }\right)$ at the depths of the $P-E$ experiments. (B) Relationship between $\mu_{\max }$ and proportion of eukaryotic cells in total picophytoplankton abundance for all data pooled. Fitted line represents Model II linear regression: $\mu_{\max }=0.29+0.02 \%$ eukaryotic cells; $r^{2}=0.36, p=0.002, n=24$ 


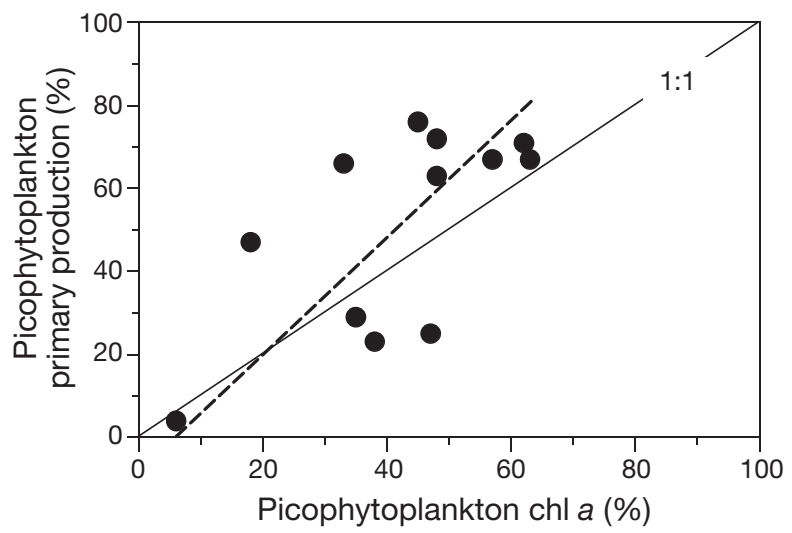

Fig. 7. Relationship between picophytoplankton relative

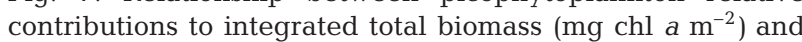
primary production $\left(\mathrm{mg} \mathrm{C} \mathrm{m}^{-2} \mathrm{~d}^{-1}\right)$ during 2003. Fitted line represents Model II linear regression detailed in the text. The 1:1 line is shown for visual reference

deep values for $\mu_{\max }$ were highly correlated ( $\mathrm{r}=0.90$, $\mathrm{p}<0.001, \mathrm{n}=12$ ) and displayed very similar seasonal patterns (cf. Fig. 4B). By normalizing maximum picophytoplankton photosynthetic rates to carbon biomass rather than chl a concentration, differences due to sampling depth were clearly smoothed (paired $t$-test, $\mathrm{p}=0.48, \mathrm{n}=12$ ). With all data pooled, picophytoplankton maximum growth rates were related to the proportion of picoeukaryotes to total numbers, with significantly higher $\mu_{\max }$ when eukaryotic cells dominated the community (Fig. 6B).

The relative contributions of picophytoplankton to chl $a$ and primary production rates were significantly correlated (Fig. 7) and were described by the following Model II linear regression: \%pico-PP $=-8.03+$ $1.41 \%$ pico-chl $a, \mathrm{r}^{2}=0.44, \mathrm{p}=0.02, \mathrm{n}=12$. Although picophytoplankton contribution to primary production was generally higher than to chl a (8 out of 12 months), differences were not statistically significant (paired $t$ test, $\mathrm{p}=0.11, \mathrm{n}=12$ ).

\section{DISCUSSION}

The marked spatio-temporal differences in picophytoplankton abundance, composition and biomass frequently observed in coastal ecosystems (Jacquet et al. 2006, Rodríguez et al. 2006) are due to the highly hydrodynamic nature of shelf waters and its effects in the nutrient regime. Seasonal variations in picophytoplankton composition found during this study were very similar to those previously reported by CalvoDíaz \& Morán (2006) at the same station in the southern Bay of Biscay continental shelf, although a greater abundance of Prochlorococcus and Synechococcus was observed here during autumn. Indeed, cyanobacteria were more abundant during 2003 than in any other year throughout the time-series that began in April 2002 (Calvo-Díaz et al. in press). Water mass advection onto the shelf related to the prevailing wind regime in the region (Ruiz-Villarreal et al. 2006) is currently the most likely explanation for the presence of Prochlorococcus from August or September to January or February. Insufficient instrument sensitivity (Worden et al. 2004) is not a plausible explanation for the absence of this cyanobacteria during the rest of the year, since in vivo analyses are also performed in parallel to fixed samples in my laboratory. Calvo-Díaz et al. (2004) suggested that Prochlorococcus were possibly passively transported by the Iberian Poleward Current, also known as the Portugal Coastal Counter Current or 'Navidad' Current. However, accumulated evidence does not support this as the sole explanation, since the beginning of the period of absence of Prochlorococcus frequently coincides with the most marked signal of this current in the southern Bay of Biscay (GonzálezNuevo \& E. Nogueira pers. comm.).

Seasonal variations in cell size were too low (Table 2) relative to changes in abundance to significantly influence fluctuations of picophytoplankton biomass over time. As in previous studies conducted in other European coastal regions (e.g. Joint et al. 1986, Kuosa 1991, Bec et al. 2005), maximum standing stocks were observed in summer and autumn (Fig. 2, Table 3) as a consequence of temperatureassociated maxima in abundance during those seasons (Li et al. 2006). Higher-amplitude variations in picophytoplankton biomass compared with chl a (Table 3) underlie the clear seasonality shown by the euphotic-layer integrated C:chl a ratios (Fig. 3), which are very consistent in the study area. An overall range of $<10$ to 140 for this ratio over a 4 yr period has been described by Calvo-Díaz et al. (in press). This is within the expected range for bulk phytoplankton assemblages (Geider 1987), although some studies have identified lower values for the smallest phytoplankton size fraction (Arin et al. 2002).

\section{Picophytoplankton photosynthetic parameters}

Seasonality in the photosynthetic parameters $P^{\mathrm{B}}{ }_{\mathrm{m}}, \alpha^{\mathrm{B}}$ and $E_{\mathrm{k}}$ of picophytoplankton was clearly different at the surface and deeper in the water column (Fig. 4). The overall opposite behaviour of picophytoplanktonic $P_{\mathrm{m}}^{\mathrm{B}}$ and $\alpha^{\mathrm{B}}$ at the surface is in general agreement with the variation recently reported by Morán \& Estrada (2005) for bulk phytoplankton assemblages in the western Mediterranean. The stronger correlation with environmental irradiance found by these authors is 
likely due to the fact that their values were averages of several within-cruise determinations rather than single points. High short-term variability in photosynthetic performance is well known (Côté \& Platt 1983, Morán \& Estrada 2001, Morán et al. 2002). Notwithstanding the limited representativeness of single-month measurements, similar seasonal patterns in surface $P_{\mathrm{m}}^{\mathrm{B}}$ and $E_{\mathrm{k}}$ have been reported by Tillmann et al. (2000) and Shaw \& Purdie (2001) for bulk phytoplankton in the North Sea. Similarly, highest $P_{\mathrm{m}}^{\mathrm{B}}$ values of surface picophytoplankton were observed in summer in Lake Kinneret by Malinsky-Rushansky et al. (1997), when prokaryotes prevailed over eukaryotes. Overall, my $P^{\mathrm{B}}$ values encompassed a slightly greater range of variation than Stockner's (1988) review of marine and freshwater ecosystems: 0.3 to $14.5 \mathrm{mg} \mathrm{C} \mathrm{mg} \mathrm{chl} a^{-1} \mathrm{~h}^{-1}$.

Even though deep samples were collected within the mixed layer in January to April and October to December, $\alpha^{\mathrm{B}}$ was consistently higher at depth than at the surface throughout the year (Fig. 4A). This result suggests that photoacclimation in picophytoplankton is a very fast process, at least where the light-limited portion of the $P$-E response is concerned. In contrast, surface and deep values of $P_{\mathrm{m}}^{\mathrm{B}}$ and $E_{\mathrm{k}}$ only became markedly different from July through October (Fig. 4), coincident with the period of strong stratification of the water column (Fig. 1A). Although taxonomical changes within the picoeukaryotic groups were not investigated, the vertical distribution of flow-cytometric fluorescence and size signals of cyanobacteria would suggest a gradual photoacclimation rather than the selection of a different community at depth. Furthermore, the difference between surface and deep $P_{\mathrm{m}}^{\mathrm{B}}$ values was significantly correlated with stratification index (Fig. 5A), indicating that the longer the residence time, the higher the shade acclimation of low irradiance populations by decreasing $P_{\mathrm{m}}^{\mathrm{B}}$, as found elsewhere for the entire phytoplankton assemblage (Falkowski 1981, Lewis et al. 1984), and specifically for the picoplankton size fraction (Furnas \& Mitchell 1988). However, $\alpha^{B}$ need not lower mixing rates to become higher at depth (Fig. 4A) and hence bears no significant relationship with increased stratification (Fig. 5B). This different behaviour of $P_{m}^{\mathrm{B}}$ and $\alpha^{\mathrm{B}}$ throughout the annual cycle is striking when compared with studies of photosynthetic parameters of the whole autotrophic community. Morán \& Estrada (2001) have reported parallel decreases in $P^{\mathrm{B}}$ and $\alpha^{\mathrm{B}}$ when the water column was not strongly stratified. Indeed, concurrent changes of $P^{\mathrm{B}}$ and $\alpha^{\mathrm{B}}$ in the same direction are obviously necessary if we are to find the frequently reported ' $E_{\mathrm{k}}$-independent' variability (Behrenfeld et al. 2004) of photosynthetic parameters. Bearing in mind the limitations of a seasonal cycle based on 12 discrete samples, I found $E_{\mathrm{k}}$-independent variability for the
$>2 \mu \mathrm{m}$ fraction $(\mathrm{r}=0.68, \mathrm{p}<0.001, \mathrm{n}=24)$ but not for the picophytoplankton ( $p=0.65)$, suggesting some fundamental difference in the photoacclimation response of both size fractions.

Another interesting difference with larger phytoplankton is the consistently higher $P_{\mathrm{m}}^{\mathrm{B}}$ values of picophytoplankton compared with the $>2 \mu \mathrm{m}$ fraction; this is in agreement with the works of Furnas \& Mitchell (1988) in open-ocean Coral Sea waters and Madariaga \& Joint (1994) in the North Sea, but in contrast with the results of Cermeño et al. (2005) for the Ría de Vigo. Although biomass measurements of the nano- and microplankton size fractions were not available, C: chl a ratios of larger size classes are similar or higher than values observed here for picophytoplankton (Arin et al. 2002). Therefore, my results suggest that, as other studies (e.g. Jacquet et al. 2006) have found, the dominance of large phytoplankton cells under nutrient- and light-sufficient conditions (from roughly March to May in this region, Calvo-Díaz et al. in press) cannot be explained by the intrinsic capacity of larger cells to grow faster (Fernández et al. 2003) when they are not limited by nutrient diffusion. However, it is possible that the large (nano- plus micro-) vs. small (picoplankton) opposition is of minor importance here compared with the specific taxonomic composition of the large phytoplankton group, which includes fast-growing diatoms, but also dinoflagellates with lower specific growth rates.

\section{Picophytoplankton growth rates}

Using data of ${ }^{14} \mathrm{C}$-based primary production for estimating phytoplankton growth rates has sometimes resulted in much lower values when compared with dilution-growth experiments (Moigis 1999). Therefore, maximum $\left(\mu_{\max }\right)$ and effective $(\mu)$ growth rates given here should be considered as conservative estimates. Marra (2002) has proposed that short $(<6 \mathrm{~h})$ radiocarbon incubations yield production rates closer to net rather than gross; however, a recent analysis (Latasa et al. 2005) has shown a very good correspondence between both methods when primary production was estimated from short $P-E$ relationships like the ones used here. Furthermore, the range of variation of picophytoplankton $\mu\left(0.1\right.$ to $\left.1.6 \mathrm{~d}^{-1}\right)$ and $\mu_{\max }\left(0.1\right.$ to $\left.-3.1 \mathrm{~d}^{-1}\right)$ in the region considered here compares well with dilution-based estimates from other areas (Reckermann \& Veldhuis 1997, Bec et al. 2005), although values are substantially higher than those obtained by in the oligotrophic Atlantic by Marañón et al. (2003) (0.2 to $\left.0.3 \mathrm{~d}^{-1}\right)$, who also used fractionated ${ }^{14} \mathrm{C}$ uptake and biomass measurements for estimating $\mu$. 
These results also suggest a relationship between growth rate and the dominant cell organization within the community (Fig. 6B). Both the small- and largeflow cytometrically determined eukaryotic groups likely encompass a large genetic variability throughout the annual cycle (Medlin et al. 2006), in contrast to the more homogeneous clusters of Prochlorococcus spp. and Synechococcus spp. prokaryotic cells. However, regardless of the specific composition, the contribution of eukaryotes to total picophytoplankton numbers was positively correlated with $\mu_{\max }$ values (Fig. 6B), suggesting that eukaryotic cells outgrew cyanobacteria and contributed a larger fraction of total carbon fixation by picophytoplankton. This is supported by several direct $\mu$ determinations from dilution experiments. In their seasonal cycle study of a Mediterranean coastal lagoon, Bec et al. (2005) found that picoeukaryotes always presented higher growth rates than cyanobacteria, and Lignell et al. (2003) found that nutrient-replete $\mu$ of the whole phytoplanktonic community in the Baltic coastal zone ranged from 0.1 to $0.7 \mathrm{~d}^{-1}$, with small ( 2 to $10 \mu \mathrm{m}$ ) algae growing faster (up to $1.5 \mathrm{~d}^{-1}$ ) than cyanobacteria. Latasa et al. (2005) also argued that the relatively high growth rates they measured in summer in the Mediterranean were related to the overwhelming presence of eukaryotes within a community dominated by small phytoplankton. These results indicate that the picophytoplankter condition does not imply a common photosynthetic response for all the members of this size class (Raven 1998), with the eukaryotic cell type performing better than the prokaryotic one, at least in coastal ecosystems. Since changes in flow cytometrically determined populations are easy to monitor, eukaryote-toprokaryote ratios may be useful as a proxy of picophytoplankton photosynthetic performance, although future research is needed to confirm the simple relationship suggested here.

\section{Significance of picophytoplankton for coastal carbon fluxes}

Effective growth rates of picophytoplankton populations were frequently close to 1 division $\mathrm{d}^{-1}$ (Table 3). Taken together with the biomass contributed by the 4 groups considered, which jointly often exceeded $0.5 \mathrm{~g} \mathrm{C} \mathrm{m}^{-2}$ during 2003, these growth rates indicate that picophytoplankton was the most important size fraction of primary producers at the sampled station for two-thirds of the year (Table 3); during the remaining months, only in April did the contribution of picophytoplankton to overall primary production drop below $20 \%$. However, I did not find strong evidence (Fig. 7) of differences in the relative contribution of picoplankton to biomass or to production, contrary to the findings of Cermeño et al. (2006) in the Ría de Vigo, which they attributed to a higher photosynthetic efficiency of larger cells (Cermeño et al. 2005). Rather, maximum photosynthetic rates were significantly higher for picophytoplankton than for the $>2 \mu \mathrm{m}$ size fraction. The specific composition of autotrophic picoplankton at both sites is different, e.g. Synechococcus usually does not attain as high abundances in the Ría Vigo as those found in the Cantabrian Sea (Morán et al. 2002, Calvo-Díaz et al. 2004, Calvo-Díaz \& Morán 2006) and Prochlorococcus is rare and sporadic in the Ría de Vigo (Cermeño et al. 2006, Rodríguez et al. 2006).

These results add to the still-sparse dataset dealing with the role of picophytoplankton in shelf waters (Joint \& Pomroy 1986, Jochem 1989, Mousseau et al. 1996, Cermeño et al. 2006). A mean annual contribution to phytoplankton biomass and production close to $50 \%$ is not very different from what is found in openocean oligotrophic waters (Agawin et al. 2000, Ignatiades et al. 2002, Pérez et al. 2006). Since the beginning of the picophytoplankton time-series in 2001, the highest abundance of Prochlorococcus cells was observed in 2003 (X. A. G. Morán, A. Calvo-Díaz \& L. A. Suárez unpubl. data); hence, prokaryotic numbers are usually lower at this station. However, given the apparently higher growth rates with increasing dominance of eukaryotic cells (Fig. 6B), and the rather constant annual mean contribution of this size class to total chl a (35 to $45 \%$ ), my results suggest that picoautotrophs are fundamental components of planktonic food webs and carbon flow in temperate, coastal ecosystems subject to spring diatom blooms. A similar result for ultraphytoplankton (i.e. $<5 \mu \mathrm{m}$, which accounted for $52 \%$ of total chl $a$ and $56 \%$ of total primary production) was found in the Scotian Shelf by Mousseau et al. (1996). These results support the hypothesis that, except for the spring bloom characterized by a clear but shortlived dominance of large phytoplankton ( $\mathrm{Li}$ et al. 2006), small cells make up significant contributions to the annual organic carbon input of mesotrophic coastal waters.

I suspect that these results are somewhat unexpected partly due to a conventional, yet largely untested, wisdom that tends to restrict picophytoplankton dominance to open-ocean, oligotrophic regions. As noted in the 'Introduction,' few studies have systematically assessed the role of picophytoplankton production in coastal waters. Picoplankton was the single most important size fraction of the 3 commonly considered $(<2,2$ to 20 and $>20 \mu \mathrm{m})$ to contribute to total phytoplankton photosynthesis in the southern Bay of Biscay continental shelf. This finding is explained by 2 factors: first, an annual average close 
to half the total phytoplankton biomass expressed as chl a (Table 3), and second, consistently higher $P_{\mathrm{m}}^{\mathrm{B}}$ values (2-fold on average) than their larger counterparts. If, as several studies have pointed out, we are to foresee pelagic planktonic food webs increasingly shifted to smaller size fractions (e.g. Karl et al. 2001) as a consequence of global change, the results presented here might be considered as a baseline to which future appraisals could be compared. In any case, while picoplanktonic dominance of primary production needs further seasonal studies from other shelf regions in order to assess its generality, I conclude that picophytoplankton should not be routinely dismissed as a minor component of carbon fluxes in coastal ecosystems any longer.

Acknowledgements. I am indebted to A. Calvo-Díaz and L. A. Suárez for their help with $P-E$ determinations and flow cytometry analysis, respectively. M. Maiques made chlorophyll determinations and nutrients were analyzed by N. González and C. Carballo. M. Estrada and Á. López-Urrutia provided valuable comments on the original manuscript. Critical comments by $\mathrm{H}$. MacIntyre and 2 anonymous reviewers helped improve the final version. This work was supported by the Spanish research grant VARIPLACA (CICYT, REN20010345/MAR) and the time-series programme RADIALES of the Instituto Español de Oceanografía.

\section{LITERATURE CITED}

Agawin NSR, Duarte CM, Agustí S (2000) Nutrient and temperature control of the contribution of picoplankton to phytoplankton biomass and production. Limnol Oceanogr 45:591-600

Arin L, Morán XAG, Estrada M (2002) Phytoplankton size distribution and growth rates in the Alboran Sea (SW Mediterranean): short term variability related to mesoscale hydrodynamics. J Plankton Res 24:1019-1033

Bec B, Husseini-Ratrema J, Collos Y, Souchu P, Vaquer A (2005) Phytoplankton seasonal dynamics in a Mediterranean coastal lagoon: emphasis on the picoeukaryote community. J Plankton Res 27:881-894

Behrenfeld MJ, Prasil O, Babin M, Bruyant F (2004) In search of a physiological basis for covariations in light-limited and light-saturated photosynthesis. J Phycol 40:4-25

Calvo-Díaz A, Morán XAG (2006) Seasonal dynamics of picoplankton in shelf waters of the southern Bay of Biscay. Aquat Microb Ecol 42:159-174

Calvo-Díaz A, Morán XAG, Nogueira E, Bode A, Varela M (2004) Picoplankton community structure along the northern Iberian continental margin in late winter-early spring. J Plankton Res 26:1069-1081

Calvo-Díaz A, Morán XAG, Suárez LÁ (in press) Seasonality of picophytoplankton chlorophyll $a$ and biomass in the central Cantabrian Sea, southern Bay of Biscay. J Mar Syst

Carrick HJ, Schelske CL (1997) Have we overlooked the importance of small phytoplankton in productive waters? Limnol Oceanogr 42:1613-1621

Cermeño P, Estévez-Blanco P, Marañón E (2005) Maximum photosynthetic efficiency of size-fractionated phytoplankton assessed by ${ }^{14} \mathrm{C}$ uptake and fast repetition rate fluorometry. Limnol Oceanogr 50:1438-1446
Cermeño P, Marañón E, Pérez V, Serret P, Fernández E, Castro CG (2006) Phytoplankton size structure and primary production in a highly dynamic coastal ecosystem (Ria de Vigo, NW-Spain): seasonal and short-time scale variability. Estuar Coast Shelf Sci 67:251-266

Côté B, Platt T (1983) Day-to-day variations in the springsummer photosynthetic parameters of coastal marine phytoplankton. Limnol Oceanogr 28:320-344

Falkowski PG (1981) Light-shade adaptation and assimilation numbers. J Plankton Res 3:203-216

Fernández E, Marañón E, Morán XAG, Serret P (2003) Potential causes for the unequal contribution of picophytoplankton to total biomass and productivity in oligotrophic waters. Mar Ecol Prog Ser 254:101-109

Finenko ZZ, Churilova TY, Sosik HM, Basturk O (2002) Variability of photosynthetic parameters of the surface phytoplankton in the Black Sea. Oceanology 42:60-75

Furnas MJ, Mitchell AW (1988) Photosynthetic characteristics of Coral Sea picoplakton $(<2 \mu \mathrm{m}$ size fraction). Biol Oceanogr 5:163-182

Geider RJ (1987) Light and temperature-dependence of the carbon to chlorophyll a ratio in microalgae and cyanobacteria: implications for physiology and growth of phytoplankton. New Phytol 106:1-34

Ignatiades L, Psarra S, Zervakis V, Pagou K, Souvermezoglou E, Assimakopolou G, Gotsis-Skretas O (2002) Phytoplankton size-based dynamics in the Aegean Sea (Eastern Mediterranean). J Mar Syst 36:11-28

Iriarte A, Purdie DA (1994) Size distribution of chlorophyll a biomass and primary production in a temperate estuary (Southampton Water): the contribution of photosynthetic picoplankton. Mar Ecol Prog Ser 115:283-297

Jacquet S, Delesalle B, Torreton JP, Blanchot J (2006) Response of phytoplankton communities to increased anthropogenic influences (southwestern lagoon, New Caledonia). Mar Ecol Prog Ser 320:65-78

Jochem F (1989) Distribution and importance of autotrophic ultraplankton in a boreal inshore area (Kiel Bight, Western Baltic). Mar Ecol Prog Ser 53:153-168

Joint IR, Pomroy AJ (1983) Production of picoplankton and small nanoplankton in the Celtic Sea. Mar Biol 77:19-27

Joint IR, Pomroy AJ (1986) Photosynthetic characteristics of nanoplankton and picoplankton from the surface mixed layer. Mar Biol 92:465-474

Joint I, Rees AP, Woodward EMS (2001) Primary production and nutrient assimilation in the Iberian upwelling in August 1998. Prog Oceanogr 51:303-320

Karl DM, Bidigare RR, Letelier RM (2001) Long-term changes in plankton community structure and productivity in the North Pacific Subtropical Gyre: the domain shift hypothesis. Deep-Sea Res II 48:1449-1470

Kuosa H (1991) Picoplanktonic algae in the northern Baltic Sea: seasonal dynamics and flagellate grazing. Mar Ecol Prog Ser 73:269-276

Latasa M, Morán XAG, Scharek R, Estrada M (2005) Estimating the carbon flux through main phytoplankton groups in the northwestern Mediterranean. Limnol Oceanogr 50: $1447-1458$

Lewis MR, Cullen JJ, Platt T (1984) Relationships between vertical mixing and photoadaptation of phytoplankton: similarity criteria. Mar Ecol Prog Ser 15:141-149

Li WKW, Harrison WG, Head EJH (2006) Coherent assembly of phytoplankton communities in diverse temperate ocean ecosystems. Proc R Soc Lond B 273:1953-1960

Lignell R, Seppälä J, Kuuppo P, Tamminen T, Andersen T, Gismervik I (2003) Beyond bulk properties: Responses of coastal summer plankton communities to nutrient enrich- 
ment in the northern Baltic Sea. Limnol Oceanogr 48: 189-209

MacIntyre HL, Kana TM, Anning T, Geider RJ (2002) Photoacclimation of photosynthesis irradiance response curves and photosynthetic pigments in microalgae and cyanobacteria. J Phycol 38:17-38

Madariaga I, Joint I (1994) Photosynthesis and carbon metabolism by size-fractionated phytoplankton in the southern North Sea in early summer. Cont Shelf Res 14: 295-311

Magazzù G, Decembrini F (1995) Primary production, biomass and abundance of phototrophic picoplankton in the Mediterranean Sea: a review. Aquat Microb Ecol 9:97-104

Malinsky-Rushansky NZ, Berman T, Dubinsky Z (1997) Seasonal photosynthetic activity of autotrophic picoplankton in Lake Kinneret, Israel. J Plankton Res 19:979-993

Marañón E, Behrenfeld MJ, González N, Mouriño B, Zubkov MV (2003) High variability of primary production in oligotrophic waters of the Atlantic Ocean: uncoupling from phytoplankton biomass and size structure. Mar Ecol Prog Ser 257:1-11

Marra J (2002) Approaches to the measurement of plankton production. In: Williams PJleB, Thomas DN, Reynolds CS (eds) Phytoplankton productivity. Carbon assimilation in marine and freshwater ecosystems. Blackwell Science, Oxford, p 78-108

Medlin LK, Metfies K, Mehl H, Wiltshire K, Valentin K (2006) Picoeukaryotic plankton diversity at the Helgoland time series site as assessed by three molecular methods. Microb Ecol 52:53-71

Moigis AG (1999) Photosynthetic rates in the surface waters of the Red Sea: the radiocarbon versus the non-isotopic dilution method. J Plankton Res 22:713-727

Morán XAG, Estrada M (2001) Short-term variability of photosynthetic parameters and particulate and dissolved primary production in the Alboran Sea (SW Mediterranean). Mar Ecol Prog Ser 212:53-67

Morán XAG, Estrada M (2005) Winter pelagic photosynthesis in the NW Mediterranean. Deep-Sea Res I 52:1806-1822

Morán XAG, Gasol JM, Pedrós-Alió C, Estrada M (2002) Partitioning of phytoplanktonic organic carbon production and bacterial production along a coastal-offshore gradient in the NE Atlantic during different hydrographic regimes. Aquat Microb Ecol 29:239-252

Mousseau L, Legendre L, Fortier L (1996) Dynamics of sizefractionated phytoplankton and trophic pathways on the

Editorial responsibility: Hugh MacIntyre,

Dauphin Island, Alabama, USA
Scotian Shelf and at the shelf break, northwest Atlantic. Aquat Microb Ecol 10:149-163

Murrell MC, Lores EM (2004) Phytoplankton and zooplankton seasonal dynamics in a subtropical estuary: importance of cyanobacteria. J Plankton Res 26:371-382

Pérez V, Fernández E, Marañón E, Morán XAG, Zubkov MV (2006) Vertical distibution of phytoplankton biomass, production and growth in the Atlantic subtropical gyres. Deep-Sea Res I 53:1616-1634

Platt T, Gallegos CL, Harrison WG (1980) Photoinhibition of photosynthesis in natural assemblages of marine phytoplankton. J Mar Res 38 (4):687-701

Raven JA (1998) The twelfth Tansley Lecture. Small is beautiful: the picophytoplankton. Funct Ecol 12:503-513

Reckermann M, Veldhuis MJW (1997) Trophic interactions between picophytoplankton and micro- and nanozooplankton in the western Arabian Sea during the NE monsoon 1993. Aquat Microb Ecol 12:263-273

Rodríguez F, Garrido JL, Crespo BG, Arbones B, Figueiras FG (2006) Size-fractionated phytoplankton pigment groups in the NW Iberian upwelling system: impact of the Iberian Poleward Current. Mar Ecol Prog Ser 323:59-73

Ruiz-Villarreal M, González-Pola C, Diaz del Rio G, Lavin A, Otero P, Piedracoba S, Cabanas JM (2006) Oceanographic conditions in North and Northwest Iberia and their influence on the Prestige oil spill. Mar Pollut Bull 53:220-238

Shaw PJ, Purdie DA (2001) Phytoplankton photosynthesisirradiance parameters in the near-shore UK coastal waters ot the North Sea: temporal variation and environmental control. Mar Ecol Prog Ser 216:83-94

Stockner JG (1988) Phototrophic picoplankton: an overview from marine and freshwater ecosystems. Limnol Oceanogr 33:765-775

Tillmann U, Hesse KJ, Colijn F (2000) Planktonic primary production in the German Wadden Sea. J Plankton Res 22: 1253-1276

Webb WL, Newton M, Starr D (1974) Carbon dioxide exchange of Alnus rubra: a mathematical model. Oecologia 17:281-291

Welschmeyer NA (1994) Fluorometric analysis of chlorophyll $\mathrm{a}$ in the presence of chlorophyll $\mathrm{b}$ and phaeopigments. Limnol Oceanogr 39:1985-1992

Worden AZ, Nolan JK, Palenik B (2004) Assessing the dynamics and ecology of marine picophytoplankton: the importance of the eukaryotic component. Limnol Oceanogr 49:168-179

Submitted: April 17, 2007; Accepted: September 18, 2007

Proofs received from author(s): November 21, 2007 